\title{
Avoiding conflicts and protecting coral reefs: customary management benefits marine habitats and fish biomass
}

\author{
Stuart J. Campbell, Joshua E. Cinner, Rizya L. Ardinijaya, Shinta Pardede \\ Tasrif Kartawijaya, Ahmad Mukmunin, Yudi Herdiana, Andrew S. Hoey \\ MORGAN S. PRATCHETT and ANDREW H. BAIRD
}

\begin{abstract}
One of the major goals of coral reef conservation is to determine the most effective means of managing marine resources in regions where economic conditions often limit the options available. For example, no-take fishing areas can be impractical in regions where people rely heavily on reef fish for food. In this study we test whether coral reef health differed among areas with varying management practices and socio-economic conditions on Pulau Weh in the Indonesian province of Aceh. Our results show that gear restrictions, in particular prohibiting the use of nets, were successful in minimizing habitat degradation and maintaining fish biomass despite ongoing access to the fishery. Reef fish biomass and hard-coral cover were two- to eight-fold higher at sites where fishing nets were prohibited. The guiding principle of the local customary management system, Panglima Laot, is to reduce conflict among community members over access to marine resources. Consequently, conservation benefits in Aceh have arisen from a customary system that lacks a specific environmental ethic or the means for strong resource-based management. Panglima Laot includes many of the features of successful institutions, such as clearly defined membership rights and the opportunity for resource users to be involved in making, enforcing and changing the rules. Such mechanisms to reduce conflict are the key to the success of marine resource management, particularly in settings that lack resources for enforcement.
\end{abstract}

Keywords Aceh, coral reefs, fisheries, gear restrictions, Indonesia, marine protected areas, Panglima Laot

Stuart J. Campbell, Rizya L. Ardiwijaya*, Shinta Pardede, Tasrif KartaWijaya, Ahmad Mukmunin and Yudi Herdiana The Wildlife Conservation Society, Indonesia Marine Program, Bogor, Indonesia

Joshua E. Cinner, Andrew S. Hoey†, Morgan S. Pratchett and Andrew H. BAIRD (Corresponding author) Australian Research Council Centre of Excellence for Coral Reef Studies, School of Marine and Tropical Marine Biology, James Cook University, Townsville, Quensland 4811, Australia. E-mail andrew.baird@jcu.edu.au

${ }^{*}$ Also at: The Nature Conservancy, Indonesia Marine Program, SanurDenpasar, Indonesia

†Also at: Red Sea Research Center, King Abdullah University of Science and Technology, Thuwal, Saudi Arabia

Received 28 October 2011. Revision requested 7 February 2012.

Accepted 27 February 2012.

\section{Introduction}

cross the Indo-Pacific marine resources are often $\Lambda_{\text {managed by common property arrangements that }}$ limit access through closures of fishing grounds and gear restrictions (Thornburn, 2001; Harkes \& Novaczek, 2002; Cinner \& Aswani, 2007). Benefits of these customary practices include increases in fisheries yields (McClanahan et al., 1997), biomass of target species (Cinner et al., 2005a,b) and abundance (Aswani \& Sabetian, 2010). Important ecosystem processes, such as herbivory (Aswani et al., 2007), and metrics of ecosystem health, such as coral cover, are often higher in areas under customary management (Baird et al., 2005). Integrating these customary systems with contemporary management practices (e.g. spatially defined marine protected areas) is an area of active research (Johannes, 2002; Aswani et al., 2007), with these alternate forms of marine resource management increasingly being advocated (Graham et al., 2008).

Customary management systems are frequently motivated by utilitarian social and economic goals rather than any conservation ethic (Polunin, 1984; Pannell, 1996; Cinner \& Aswani, 2007). The ability of customary systems to meet community needs such as providing fish for harvest, reducing conflict among resource users and improving yields can lead to higher levels of compliance, and ultimately better ecological outcomes. than externally imposed biodiversity conservation (McClanahan et al., 2006a; Cinner \& Aswani, 2007). One of the critical challenges for marine conservation in developing countries, where food security often takes priority over conservation goals, is how to make conservation more compatible with community needs (Drew, 2005; Cinner et al., 2007). Governance systems that respect customary knowledge, rules and decision-making processes are more likely to be supported by local communities (Aswani, 2005; Hoffman, 2006; Tiraa, 2006) and are common in many Pacific societies (Cinner \& McClanahan, 2006; Aswani et al., 2007; Cinner \& Aswani, 2007).

Compared with marine customary management in central and eastern Pacific societies there are relatively few examples of community involvement with marine resource management or marine customary law in Indonesia (Cinner \& Aswani, 2007; Cinner et al., 2012). Community 
governance structures in Indonesia have often been modified, eroded or overruled by provincial or national legal institutions (Novaczek et al., 2001; Patlis, 2003) or restricted or prejudiced by centralized conservation policies and laws with respect to marine resource access (Thornburn, 2000; Lowe, 2003), incentives for destructive fishing practices (Thornburn, 2001; Varkey et al., 2010) or disincentives for community participation in management (Novascek et al., 2001; Lowe, 2003). However, as part of the decentralization of governance in many countries, including Indonesia (Thornburn, 2001; Patlis, 2003), customary practices are becoming enshrined in the legislation of district and local authorities (Janssen, 2005; Gelcich et al., 2008).

Documenting the successes or failures of customary practices improves understanding of the governance frameworks within which marine environments and their resources are most effectively managed (McCleod et al., 2009). Here, we present a case study from Aceh, Indonesia, which examines the socio-economic and ecological conditions of six coastal communities in which a customary management system operates. Our objectives were to examine if aspects of coral reef condition, specifically hard-coral cover, fish biomass and fish assemblage structure, differed between reefs that were influenced by varying management practice, in particular the types of fishing gears restricted. To support our analysis we also investigated whether ecological variation was related to socio-economic variables, including village population size, the number of fishing households, the mean number of occupations, distance to markets, distance to villages and the number of fishing gear types prohibited.

\section{Study area and the Panglima Laot system of customary management}

This study was conducted on Pulau Weh, a high continental island located c. $20 \mathrm{~km}$ off the northern tip of Sumatra (Fig. 1). Pulau Weh has diverse coral communities that grow primarily on bedrock and in unconsolidated sediments. The coastline is divided into several lhoks (a harbour, and the unit of management in the marine realm). Within six of these lhoks we examined $1-4$ sites (15 sites in total; Fig. 1), each with its own set of restrictions on fishing gears (Table 1). One of the lhoks, Iboih, was divided into two separate areas for analysis because some sites within this lhok are managed as a special tourist reserve, Kawasan Wisata, whereas the others are managed by a Panglima Laot. Sites with both high (6-9) and low $(2-5)$ numbers of restrictions on types of fishing gear were located in lhoks on the north, east and west coasts of Pulau Weh.

In Aceh fishing communities employ a customary management system known locally as Panglima Laot. The system was first introduced in the 17 th century by Sultan

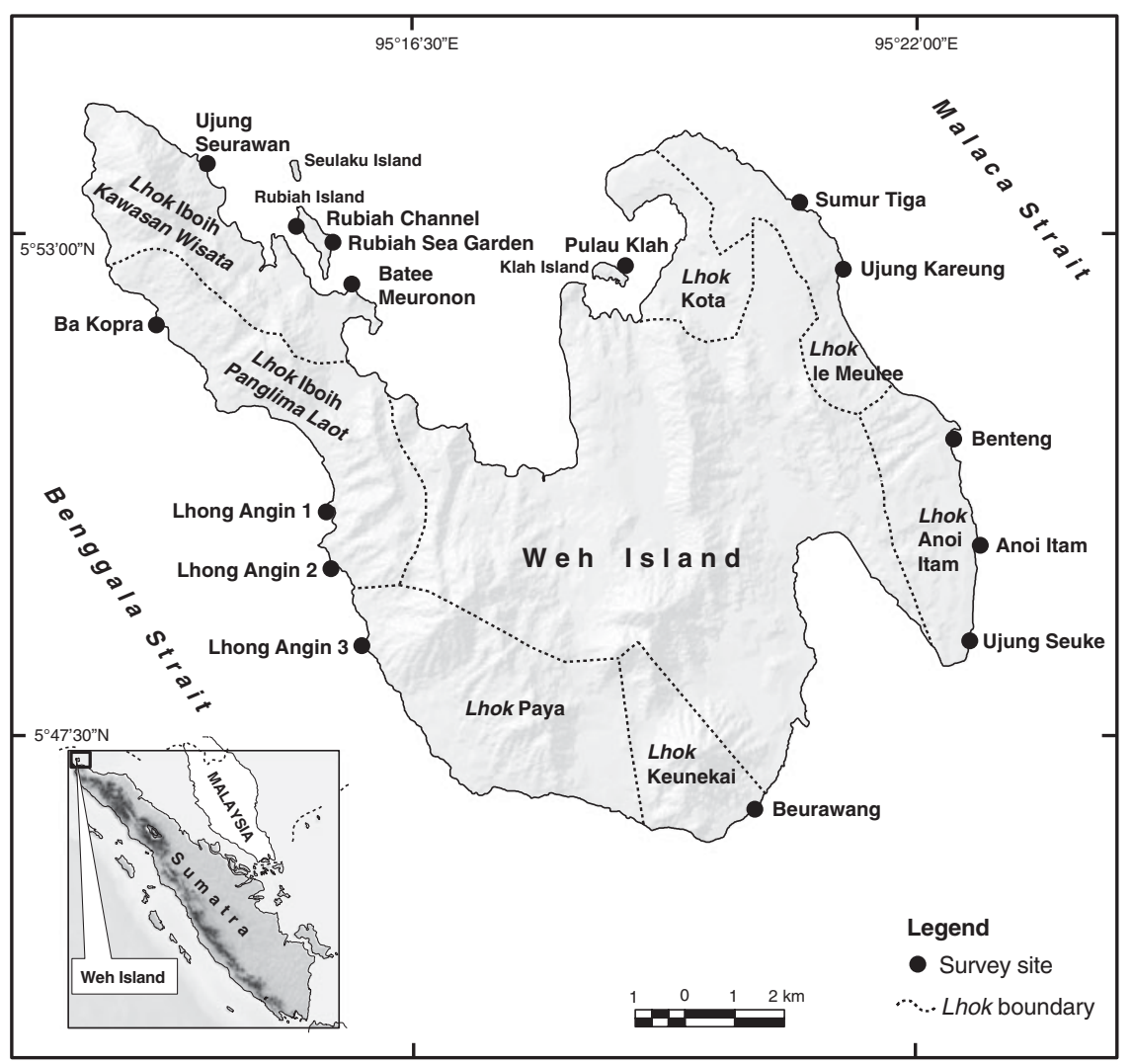

FIG. 1 Pulau Weh showing the boundaries of each of the six lhoks (Table 1) and the 15 survey sites located within these lhoks. The rectangle on the inset indicates the location of the main map off the northern tip of Sumatra. 
TABLE 1 Population size, number of fisher households, mean number of occupations and reef area in six lhoks on Pulau Weh (Fig. 1).

\begin{tabular}{lccll}
\hline Lhok & $\begin{array}{l}\text { Population } \\
\text { size }\end{array}$ & $\begin{array}{l}\text { No. of fisher } \\
\text { households }\end{array}$ & $\begin{array}{l}\text { Mean no. of } \\
\text { occupations }\end{array}$ & $\begin{array}{l}\text { Reef } \\
\text { area } \\
\text { (ha) }\end{array}$ \\
\hline $\begin{array}{l}\text { Anoi } \\
\text { Itam }\end{array}$ & 693 & 56 & 3.1 & 120.55 \\
Iboih & 766 & 52 & 2.5 & 158.65 \\
Ie & 3,574 & 60 & 2.5 & 177.9 \\
$\quad$ Meulee & & & & \\
Paya & 731 & 71 & 2.8 & 111.3 \\
Kota & 2,623 & 170 & 2.6 & 112.31 \\
Keunekai & 532 & 21 & 3.2 & 32.51 \\
\hline
\end{tabular}

Iskandar Muda (Nurdin et al., 2004). Fishers in each lhok elect an individual, usually an elder fisherman, the Panglima Laot (literally Commander of the Sea) who meets with fishers every Friday to adjudicate disputes. The Panglima Laot has the authority to adjudicate provincial laws concerning fishing rights except in cases where provincial or national criminal law is violated. The Panglima Laot decides who is entitled to the catch at sea and which fishing gears can be used. He enforces prohibitions on fishing on religious days, initiates searches for lost fishers, decides compensation in the event of boat collisions and arbitrates general disputes over access to the fisheries (Janssen, 2005). The Panglima Laot can also enforce measures to protect the marine environment from land-based threats such as poorly placed development and agriculture. Should a fisher violate the code of conduct for a given lhok, the Panglima Laot has the authority to ground a boat for 1 week at a time, and if the fisher continues to disobey the rules the Panglima Laot can banish boats from the lhok. Other sanctions include monetary fines, and preventing fishers from attending community events. Sanctions or punishments are administered through community meetings and ceremonies to reach consensus among parties (Nurdin et al., 2004). Fishers must pay a fee to enter the Panglima Laot system, which is used to cover the cost of rescues (C. Wilson, pers. comm., 2009). Importantly, the role of the Panglima Laot is not to manage fishery resources per se but rather to promote social harmony by minimizing conflict among fishers (Nurdin et al., 2004). This lack of a conservation ethic is summed up by an Acehnese proverb mentioned by Nurdin et al. (2004) to describe the philosophy behind Panglima Laot 'Uleu bak matee, ranteng bek patah'. This saying is translated by Collier et al. (2010) as 'killing a snake without breaking tree branches' or, in other words, to solve one problem without creating a new one. The role of the Panglima Laot system in marine resource management has most recently been recognized in 2008, in Provincial Laws No. 9 and 10, which give the Panglima Laot authority to arbitrate customary laws in relation to the sea.

\section{Methods}

\section{Coral cover and fish biomass}

In March 2006 coral cover and fish biomass were estimated along two replicate $50 \mathrm{~m}$ transects at two depths (3-4 and 6-8 m) at each of the 15 sites (Fig. 1). Coral cover was recorded at 100 points along each transect, spaced at $0.5 \mathrm{~m}$ intervals. Any hard coral (i.e. scleractinian or hydrozoan coral) underlying each survey point was recorded to genus.

The fish assemblages were surveyed along the same $50 \mathrm{~m}$ transects used for estimating hard-coral cover. One diver recorded all visually apparent reef fish (i.e., excluding cryptobenthic families Blenniidae, Gobiidae and Tripterygiidae) $>10 \mathrm{~cm}$ total length in a $5 \mathrm{~m}$ wide belt, and a second diver recorded all fish $<10 \mathrm{~cm}$ total length in a $2-\mathrm{m}$ wide belt that extended from the reef substratum to the surface of the water. Individual fishes were identified to species and placed into one of nine size classes $(0-5,5-10$, $10-15,15-20,20-25,25-30,30-35,35-40$ and $>40 \mathrm{~cm})$. Density estimates were converted to biomass using known length-weight relationships; $W=a L^{b}$, where $W$ is weight $(\mathrm{kg}), L$ is total length $(\mathrm{cm})$ and $a, b$ are the indices for a given species (Froese \& Pauly, 2008). To examine variation in fish assemblage structure, individual species were allocated to six trophic groups (corallivores, herbivores, invertivores, omnivores, piscivores and planktivores) following Froese \& Pauly (2008).

\section{Fishing gears of Pulau Weh}

Eight main fishing gears are used on Pulau Weh: reef nets, gill nets, mosquito nets, muroami, hookah, spearguns, handlines and trolling. Reef nets are modified seine nets, not more than $60 \mathrm{~m}$ in length, with a height of $8-10 \mathrm{~m}$ and a mesh size of $6 \mathrm{~cm}$. They are deployed after dusk from two canoes in calm waters. Gill nets target reef fish, including trigger (family Balistidae), snapper (family Lutjanidae) and emperor fish (family Lethrinidae), and consist of single nylon nets that are either small (length 300-400 m; height 2-5 m) or large (length $800-1,000 \mathrm{~m}$; height up to $15 \mathrm{~m}$ ). Mesh sizes are $4-11 \mathrm{~cm}$ and nets are set passively at the surface or at mid water. Mosquito nets are monofilament nets of 200-300 m length, with a mesh size of $<_{3} \mathrm{~mm}$, which mostly target anchovies and other small pelagic fishes. Muroami is a technique that primarily targets fusiliers (family Caesionidae) but is non-selective and can catch many reef fish species. The technique involves the use of divers and surface-supplied air (hookah) to chase fish along the reef into a large drive net or purse net (mesh size $2-5 \mathrm{~cm}$ ) set on reef slopes at depths of 7-30 $\mathrm{m}$. The crew of a muroami operation on Pulau Weh usually consists of 8-10 people. Reef nets and muroami are relatively non-selective, catching fish from many different families. Hookah 
gear consists of an air compressor with several air hoses of 50-100 m length. Hooker divers use their hands to collect sea cucumber, lobster and troches, and occasionally spears to target grouper Cephalopholis, Epinephelis and Variola spp. (family Serranidae) and gill nets to target aquarium fishes. Spearguns are made from wood, with spears 1.2-2.0 $\mathrm{m}$ in length, and are used by fishers on snorkel to target a wide variety of reef fish species, including snapper and grouper. Hook and line fishing is employed from many boat types including canoes and motorized boats, and trolling consists of a single fisher with a hook and line deployed from the rear of a motorized boat.

\section{Socio-economic variables}

In December 2006143 household surveys were conducted by $\mathrm{AM}$ and $\mathrm{YH}$ in the six lhoks. All respondents were asked to list and rank the occupations of members of the household, from which the mean number of occupations per lhok was calculated. Concurrent with these surveys demographic data were sourced from the Panglima Laot and government records. Data available for each lhok included the population size, number of households, number of households involved in fishing, and mean number of occupations per household (Table 1). At the site level data were available on the distance $(\mathrm{m})$ from survey site to the nearest village (a proxy variable for the likelihood of restrictions being enforced), the distance to the nearest fish market and the number and types of fishing gears prohibited (Table 2).

\section{Statistical analysis}

Variation in hard-coral cover and total fish biomass among lhoks and sites were tested with two nested ANOVAs. Assumptions of the ANOVA were examined using residual analysis. Subsequently total fish biomass was $\log _{10}(x+1)$ transformed to improve normality and homoscedasticity; Fisher's LSD tests were used to identify which means contributed to any significant differences among sites or lhoks.

Variation in the functional composition of the fish assemblages among lhoks was analysed using a one-factor multivariate analysis of variance (MANOVA). The analysis was based on the biomass of each of the six functional groups, and was $\log _{10}(x+1)$ transformed to improve multivariate normality. A canonical discriminant analysis was then used to examine how the lhoks differed in fish assemblage composition. Ninety-five percent confidence ellipses were plotted around the group centroids (Seber, 1984).

The relationships among the socio-economic variables and hard-coral cover and total fish biomass were examined using bivariate correlations and stepwise multiple regressions. The correlations provided an indication of the relationships between hard-coral cover and total fish biomass and each of the socio-economic variables independently, and the multiple regressions examined the combined effects of all socio-economic variables and determined the relative importance of each variable in determining coral cover and total fish biomass. All analyses were performed using STATISTICA v. 7.0 (Statsoft Inc, Tulsa, USA).

\section{Results}

The cover of hard corals varied significantly among lhoks $\left(F_{6,8}=4.22, \mathrm{P}=0.033\right)$ and sites within lhoks $\left(F_{8,42}=2.53\right.$, $\mathrm{P}=0.02)$, ranging from a mean of $10.8 \pm \mathrm{SE} 4.2 \%$ at Paya to $59.6 \pm$ SE $5.2 \%$ at Ie Meulee (Fig. 2a). Overall, coral cover was highest at Ie Meulee and Anoi Itam (54.5-59.6\%), intermediate at Iboih-Kawasan Wisata (41.9\%) and lowest at Iboih-Panglima Laot, Keunekai and Paya (10.8-30.8\%; Fig. 2a).

Total biomass of reef fish varied significantly among lhoks $\left(F_{6,8}=3.67, \mathrm{P}=0.047\right)$ but displayed no significant variation among sites $\left(F_{8,45}=1.56, \mathrm{P}=0.165\right)$. Reef fish biomass was significantly greater at Ie Meulee and Anoi Itam (1,090.4-1,729.4 $\left.\mathrm{kg} \mathrm{ha}^{-1}\right)$ than at Kota, Iboih-Panglima Laot, Keunekai and Paya (241.5-444.6 kg ha ${ }^{-1}$; Fig. 2b). The composition of the reef fish assemblages also varied significantly among lhoks on Pulau Weh (MANOVA, $\left.F_{5,85}=2.45, \mathrm{P}<0.001\right)$. The canonical discriminant analysis revealed two distinct groups of lhoks along the first canonical variate, which explained $47.4 \%$ of the total variation (Fig. 3). Anoi Itam, Ie Meulee and IboihKawasan Wisata were characterized by a greater biomass of corallivores, omnivores, herbivores, and to a lesser extent piscivores and planktivores, than Iboih-Panglima Laot, Keunekai, Kota and Paya (Fig. 3).

The cover of live hard corals was positively related to the number of fishing gears prohibited and thok population size, and negatively related to distance to village and distance to market (Table 3). The multiple regression analysis suggested that the number of fishing gear types prohibited, population size and the mean number of occupations were the best combination of predictors of hard-coral cover, with the overall model explaining $53 \%$ of the variation in coral cover among sites (Table 3). Similarly, total reef fish biomass was positively related to coral cover, the number of gear types prohibited, and negatively related to distance to nearest village and market (Table 4). The multiple regression indicated that coral cover and the number of fishing gears prohibited were the best combination of predictors of reef fish biomass, explaining 32.9 and $6.2 \%$ of the variation in fish biomass among sites, respectively (Table 4). 
TABLE 2 Distances from ecological sites to markets and village and the fishing gears prohibited $\left(^{*}\right)$ in each of the 15 sites on Pulau Weh.

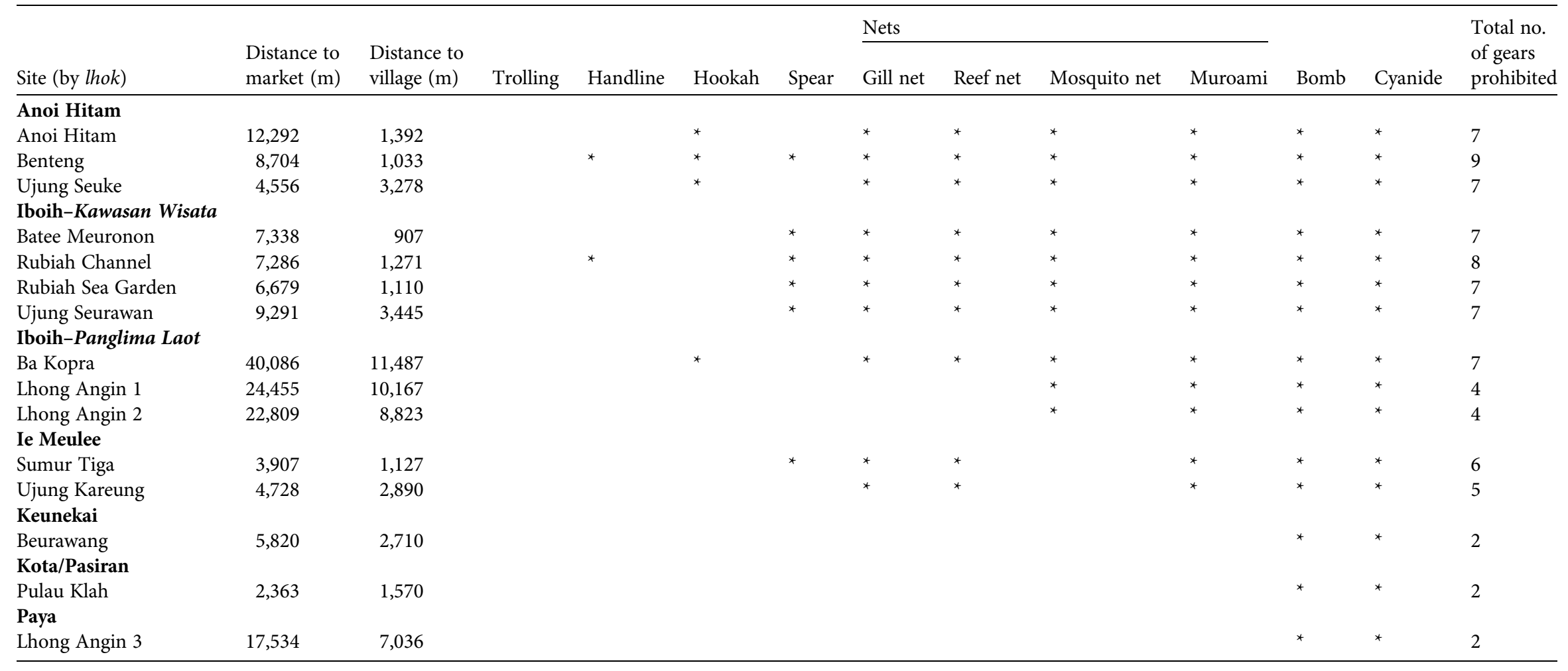



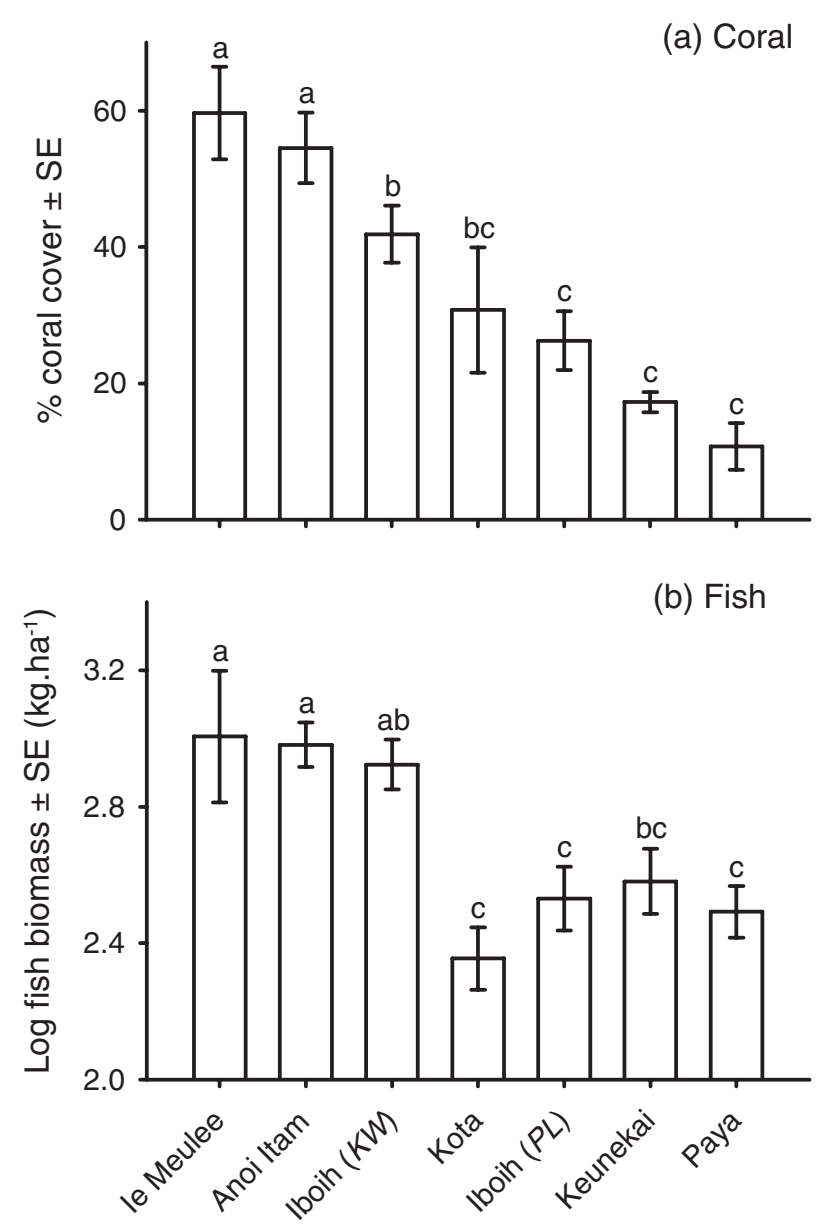

FIG. 2 Variation in (a) mean coral cover and (b) mean total fish biomass among the seven management areas (in six lhoks) on Pulau Weh (Fig. 1; KW, Kawasan Wisata; PL, Panglima Laot). Letters above each bar indicate homogeneous groups identified by Fisher's LSD post hoc analyses.

\section{Discussion}

Customary marine resource management practices in the Indo-Pacific are often focused on social goals such as minimizing conflict among coastal communities, rather than western ideals of conservation or fisheries management (Polunin, 1984; Pannell, 1996; Aswani et al., 2007). Although the primary aim of the Panglima Laot is to minimize conflict among fishers our findings indicate that controls on fishing gears indirectly yield conservation benefits, including healthier coral reefs that support a greater biomass of reef fish and important trophic groups such as herbivores that are essential for promoting reef resilience.

The correlation of coral cover with the number of gears prohibited is most likely a result of the banning of fishing gears, in particular the various types of nets that cause direct mechanical damage to corals and indirect damage by trampling from high numbers of fishers in the water to set the nets and/or scare fish into the nets. The reasons for the



FIG. 3 Canonical discriminant analysis showing the relationship among reef fish assemblages across seven management areas (in six lhoks) on Pulau Weh (Fig. 1). Ellipses represent 95\% confidence limits around the centroids for each lhok. Vectors are structural coefficients of response variables, indicating the relative contributions of each of the fish functional groups to the observed differences in assemblage composition (pl, planktivore; ps, piscivore). Dashed ellipses indicate lhoks where nets are allowed; solid ellipses are lhoks where nets are prohibited.

gear restrictions are not, however, because of potential damage to the reef but rather because some fishing gears are more likely to create conflict among fishers. Reef nets and muroami, in particular, compete with handlines and spears for many species (e.g. surgeonfish Acanthurus and Naso spp., grouper, parrotfish: Chlorurus and Scarus spp., trevally Caranx and Elagatis spp., and pelagic species such as Caesio and Scomberomorus spp.) and return relatively high rates of catch. The perception among most fishers is that nets deplete local fish stocks, with the profit mostly going to wealthy boat owners (Wildlife Conservation Society, unpubl. data). Controls enforced by the Panglima Laot on the use of nets therefore limit the perceived inequity by reducing competition among fishers of different economic status.

Many different socio-economic factors influence the ability of customary institutions to limit overexploitation of fishery resources. Generally, customary management systems operate best when the human population is low and distance to markets is great (Cinner \& Aswani, 2007; Aswani \& Sabetian, 2010) Our findings suggest an opposite trend on Pulau Weh, where the proximity of a fishing location to a village and the number of people in the lhok probably assists the Panglima Laot to enforce compliance with fishing rules, because fishing activities are in view of local communities and there are more people to watch over the resource (Crawford et al., 2004; McClanahan et al., 2006b). 
TABLE 3 Relationship between live coral cover and six socio-economic variables across 15 sites on Pulau Weh, with Pearson's correlation coefficient and the results of a stepwise multiple regression analysis.

\begin{tabular}{|c|c|c|c|c|c|c|c|}
\hline & \multicolumn{2}{|c|}{$\underline{\text { Bivariate correlation }}$} & \multicolumn{5}{|c|}{ Multiple regression } \\
\hline & $r$ & $\mathrm{P}$ & Multiple $R^{2}$ & $\beta$ & S.E. of $\beta$ & $t_{(56)}$ & $\mathrm{P}$ \\
\hline Number of gears prohibited & 0.555 & $<0.001$ & 0.308 & 0.662 & 0.094 & 7.072 & $<0.001$ \\
\hline Population & 0.306 & 0.017 & 0.487 & 0.516 & 0.100 & 5.163 & $<0.001$ \\
\hline Mean occupations & 0.032 & 0.806 & 0.533 & 0.229 & 0.098 & 2.345 & 0.023 \\
\hline Fishing households & -0.035 & 0.792 & & & & & \\
\hline
\end{tabular}

TABLE 4 Relationship between total fish biomass and six socio-economic variables and live hard-coral cover across 15 sites on Pulau Weh, with Pearson's correlation coefficient and the results of a stepwise multiple regression analysis. Total fish biomass was log-transformed.

\begin{tabular}{|c|c|c|c|c|c|c|c|}
\hline & \multicolumn{2}{|c|}{$\underline{\text { Bivariate correlation }}$} & \multicolumn{5}{|c|}{$\underline{\text { Multiple regression }}$} \\
\hline & $r$ & $\mathrm{P}$ & Multiple $R^{2}$ & $\beta$ & S.E. of $\beta$ & $t_{(57)}$ & $\mathrm{P}$ \\
\hline Coral cover & 0.574 & $<0.001$ & 0.329 & 0.347 & 0.131 & 5.338 & $<0.001$ \\
\hline Number of gears prohibited & 0.525 & $<0.001$ & 0.391 & 0.257 & 0.131 & 2.401 & 0.020 \\
\hline Population & 0.087 & 0.511 & & & & & \\
\hline Mean occupations & 0.065 & 0.622 & & & & & \\
\hline Fishing households & -0.248 & 0.056 & & & & & \\
\hline Distance to village & -0.431 & 0.001 & & & & & \\
\hline Distance to market & -0.313 & 0.015 & & & & & \\
\hline
\end{tabular}

The strong relationship between reef fish biomass and coral cover is not surprising because many reef fish rely on corals for shelter and food (Jones et al., 2004; Graham et al., 2007). Numerous studies have reported declines in reef fish diversity and abundance following declines in coral cover and structural complexity (Jones et al., 2004; Pratchett et al., 2008; Messmer et al., 2011). This result suggests that one of the most effective means of protecting fish biomass is to protect the habitat. However, the positive correlation between fish biomass and the number of fishing gears prohibited also suggests that gear restrictions are having a direct effect by reducing fishing pressure. Reef fish biomass can be ten-fold greater in marine protected areas within 10 years of closure when compared to adjacent heavily fished areas (McClanahan \& Graham, 2005; Russ et al., 2005). Similarly, in a reef fishery in Tanzania the banning of dynamite, cyanide and small-mesh seine nets that are deployed in a similar manner to muroami nets on Pulau Weh also resulted in an increased abundance of reef fish and the biomass of some fish families (Tyler et al., 2011). Although banning destructive fishing gears appears to be improving fish biomass on Pulau Weh and elsewhere (Tyler et al., 2011) effort may need to be further limited to facilitate greater improvements in fish biomass. The Panglima Laot on the east coast of Pulau Weh have recently achieved this through the establishment of strict no-take areas within their marine waters. The proximity of a site to a village can shape reef fish biomass because of market-driven demands (Brewer et al., 2009) and increased fishing pressure (Cinner \& McClanahan, 2006). In contrast, our findings suggest the proximity of a fishing location to a village probably assists the Panglima Laot to enforce compliance with fishing rules, as described above.

Reef fish populations also vary in response to environmental factors such as wave exposure, currents and primary productivity (Halford et al., 2004; Pratchett et al., 2008). Although we did not specifically control for these environmental factors, the variation in reef fish biomass was much greater (up to eight-fold) than we would predict on the basis of environmental differences alone. Furthermore, adjacent lhoks (which have similar environments) with different levels of gear restriction (i.e. Ie Meulee vs Kota; Iboih-Kawasan Wisata vs Iboih-Panglima Laot, and Anoi Itam vs Keunekai) followed the general trend of greater fish biomass where the number of gears restricted was high.

Poor enforcement of controls on destructive fishing, including blast and cyanide fishing, may also be responsible for some of the differences in coral cover and fish biomass. According to local fishers, although blast fishing ceased in the 1990s, sporadic cyanide fishing continues in some lhoks such as Paya and Keunekai and may be contributing to consistently low coral cover and reef fish biomass at these sites.

The relative abundance of the different trophic groups was also linked to gear restrictions. The three lhoks where the most types of gears were prohibited (i.e. Anoi Itam, Ie Meulee and Iboih-Kawasan Wisata) were characterized by a greater biomass of corallivores, omnivores, herbivores, and to a lesser extent piscivores and planktivores, than lhoks where the number or gears prohibited was low (i.e., IboihPanglima Laot, Keunekai, Kota and Paya; Fig. 3). Similar 
responses following spatial closures on fishing of herbivorous parrot fish has been reported in the Indo-Pacific (Aswani \& Sabetian, 2010).

The customary system of Panglima Laot has a number of the design principles identified by Ostrom (2009), and more recently examined by Gutierrez et al. (2011), to be associated with successful fisheries management institutions, including clearly defined membership rights, rules that limit resource use, the right of resource users to make, enforce and change the rules, graduated sanctions and a mechanism for conflict resolution (Cinner et al., 2012). These principles are the key to the ability of the institution to reduce conflict among communities, provide sustainable access to marine resources and limit the destruction of marine habitats. However, the institution has not been uniformly successful. In particular, reef condition in the adjacent island group of Pulau Aceh was poor in 2005, possibly because of destructive fishing and poor coastal management (Baird et al., 2005; Campbell et al., 2007). The precise causes of this breakdown of the Panglima Laot system are the focus of current research efforts in the region. Investing a single individual with authority to make all decisions poses some risk of abuse.

Motivated by the aim of producing social harmony, restrictions on gear use by the Panglima Laot in Aceh have direct conservation benefits such as high coral cover and enhanced fish biomass. Additional surveys over a wider geographical scale and over a longer period are required to reveal whether these findings also apply at larger spatial and temporal scales.

\section{Acknowledgements}

Funding for this project was provided by The Kerzner Foundation and The National Fisheries and Wildlife Foundation. We acknowledge the Pulau Weh fishing communities for allowing us to use information on their socio-economic status. We also thank Dodent Mahyiddin from Rubiah Tirta Divers and Nur Fadli and Dr Edi Rudi from Syiah Kuala University, Banda Aceh, for their assistance and help with local logistics and knowledge.

\section{References}

Aburto-Oropeza, O., Erisman, B., Galland, G.R., MascarenasOsorio, I., SAla, E. \& Ezcurra, E. (2011) Large recovery of fish biomass in a no-take marine reserve. PLoS ONE, 6, e23601.

AsWANi, S. (2005) Customary sea tenure in Oceania as a case of rightsbased fishery management: Does it work? Reviews in Fish Biology and Fisheries, 15, 285-307.

Aswani, S., Albert, S., Sabetian, A. \& Furusawa, T. (2007) Customary management as precautionary and adaptive principles for protecting coral reefs in Oceania. Coral Reefs, 26, 1009-1021.
Aswani, S. \& Sabetian, A. (2010) Implications of urbanization for artisanal parrot fish fisheries in the Western Solomon Islands. Conservation Biology, 24, 520-530.

Baird, A.H., Campbell, S.J., Anggorro, A.W., Ardiwijaya, R.L., Fadi, N., Herdiana, Y. et al. (2005) Acehnese reefs in the wake of the Asian tsunami. Current Biology, 15, 1926-1930.

Brewer, T.D., Cinner, J.E., Green, A. \& Pandolfi, J.M. (2009) Thresholds and multiple scale interactions of environment, resource use, and market proximity on reef fishery resources in the Solomon Islands. Biological Conservation, 142, 1797-1807.

Campbell, S.J., Pratchett, M.S., Anggoro, A.W., Ardiwijaya, R. L., Fadli, N., Herdiana, Y. et al. (2007) Disturbance to coral reefs in Aceh, Northern Sumatra: impacts of the Sumatra-Andaman tsunami and pre-tsunami degradation. Atoll Research Bulletin, 544, $55-78$.

Cinner, J.E. \& Aswani, S. (2007) Integrating customary management into marine conservation. Biological Conservation, 140, 201-216.

Cinner, J.E., Basurto, X., Fidelman, P., Kuange, J., Lahari, R. \& Mukminin, A. (2012) Institutional designs of customary fisheries management arrangements in Indonesia, Papua New Guinea, and Mexico. Marine Policy, 36, 278-285.

Cinner, J.E., Marnane, M.J. \& McClanahan, T.R. (2005a) Conservation and community benefits from traditional coral reef management at Ahus Island, Papua New Guinea. Conservation Biology, 19, 1714-1723.

Cinner, J.E., Marnane, M.J., McClanahan, T.R. \& Almany, G.R. (2005b) Periodic closures as adaptive coral reef management in the Indo-Pacific. Ecology and Society, 11, 31.

Cinner, J.E. \& McClanahan, T.R. (2006) Socio-economic factors that lead to overfishing in small-scale coral reef fisheries of Papua New Guinea. Environmental Conservation, 33, 73-80.

Cinner, J.E., Sutton, S.G. \& Bond, T.G. (2007) Socio-economic thresholds that affect use of customary fisheries management tools. Conservation Biology, 21, 1603-1611.

Collier, B.J., Horner, K., Machdi, S. \& Wieringa, E. (2010) Glossary. In Aceh: History, Politics and Culture (eds A. Graf, S. Schroter \& E. Wieranga), pp. 335-342. Institute of Southeast Asian Studies, Singapore.

Crawford, B.R., Siahainenia, A., Rotinsulu, C. \& Sukmara, A. (2004) Compliance and enforcement of community-based coastal resource management regulations in North Sulawesi, Indonesia. Coastal Management, 32, 39-50.

DrEW, J. (2005) Use of traditional ecological knowledge in marine conservation. Conservation Biology, 19, 1286-1293.

Froese, R. \& Pauly, D. (2008) Fishbase. Http://www.fishbase.org [accessed March 2008].

Gelcich, S., Godoy, N., Prado, L. \& Castilla, J.C. (2008) Add-on conservation benefits of marine territorial user rights fishery policies in central Chile. Ecological Applications, 18, 273-281.

Graham, N.A.J., McClanahan, T.R., MacNeil, A., Wilson, S.K., Polunin, N.V.C., Jennings, S. et al. (2008) Climate warming, marine protected areas and the ocean-scale integrity of coral reef ecosystems. PLoS ONE, 3, e3039.

Graham, N.A.J., Wilson, S.K., Jennings, S., Polunin, N.V.C., Robinson, J., Bijoux, J.P. \& Daw, T.M. (2007) Lag effects in the impacts of mass coral bleaching on coral reef fish, fisheries, and ecosystems. Conservation Biology, 21, 1291-1300.

Gutierrez, N.L., Hilborn, R. \& Defeo, O. (2011) Leadership, social capital and incentives promote successful fisheries. Nature, 470, $386-389$.

Halford, A., Cheal, A.J., Ryan, D. \& Williams, D.M.C.B. (2004) Resilience to large-scale disturbance in coral and fish assemblages on the Great Barrier Reef, Australia. Ecology, 85, 1892-1905. 
Harkes, I. \& Novaczek, I. (2002) Presence, performance, and institutional resilience of sasi, a traditional management institution in central Maluku, Indonesia. Ocean and Coastal Management, 45, 237-260.

Hoffman, T.C. (2006) The reimplementation of the Ra'ui: Coral reef management in Rarotonga, Cook Islands. Coastal Management, 30 401-418.

Janssen, H. (2005) Post-tsunami rehabilitation of fishing communities and fisheries based livelihoods in Indonesia. In Regional Workshop on Post-tsunami Rehabilitation of Fishing Communities and Fisheries-based Livelihoods, pp. 27-64. International Collective in support of Fishworkers, Chennai, India.

Johannes, R.E. (2002) The renaissance of community-based marine resource management in Oceania. Annual Review of Ecology and Systematics, 33, 317-340.

Jones, G.P., McCormick, M.I., Srinivasan, M. \& Eagle, J.V. (2004) Coral decline threatens fish biodiversity in marine reserves. Proceedings of the National Academy of Sciences of the United States of America, 101, 8251-8253.

Lowe, C. (2003) Sustainability and the question of "enforcement" in integrated coastal management. The case of Nain Island, Bunaken National Park. Indonesian Journal of Coastal and Marine Resources Management, Special Edition, 1, 49-72.

McClanahan, T.R., Glaesel, H., Rubens, J. \& Kiambo, R. (1997) The effects of traditional fisheries management on fisheries yields and the coral-reef ecosystems of southern Kenya. Environmental Conservation, 24, 105-120.

McClanahan, T.R. \& Graham, N.A.J. (2005) Recovery trajectories of coral reef fish assemblages within Kenyan marine protected areas. Marine Ecology Progress Series, 294, 241-248.

McClanahan, T.R., Marnane, M.J., Cinner, J.E. \& Kiene, W.E. (2006a) A comparison of marine protected areas and alternative approaches to coral-reef management. Current Biology, 16, 14081413.

McClanahan, T.R., Verheij, E. \& Maina, J. (2006b) Comparing the management effectiveness of a marine park and a multiple-use collaborative fisheries management area in East Africa. Aquatic Conservation: Marine and Freshwater Ecosystems, 16, 147-165.

McCleod, L., Szuster, B. \& Salm, R. (2009) Sasi and marine conservation in Raja Ampat, Indonesia. Coastal Management, 37, 656-676.

Messmer, V., Jones, G.P., Munday, P.L., Holbrook, S.J., Schmitt, R.J. \& BRooks, A.J. (2011) Habitat biodiversity as a determinant of fish community structure on coral reefs. Ecology, 92, 2285-2298.

Novaczek, I., Sopacua, J. \& Harkes, I. (2001) Fisheries management in Central Maluku, Indonesia, 1997-98. Marine Policy, $25,239-249$

Nurdin, M.H., Muazzin \& Din, M. (2004) The role of marine customary law in settling marine fishery disputes and its relation to alternative dispute resolution concept (A study in Aceh Besar District). Report No 215. Syiah Kuala Universitas, Banda Aceh, Indonesia.

Ostrom, E. (2009) A general framework for analyzing sustainability of social-ecological systems. Science, 325, 419-422.

Pannell, S. (1996) Homo nullius or 'Where have all the people gone'? Refiguring marine management and conservation approaches. Australian Journal of Anthropology, 7, 21-42.
Patlis, J. (2003) The role of law and legal institutions in determining the sustainability of integrated coastal management projects in Indonesia. Indonesian Journal of Coastal and Marine Resources, Special Edition, 1, 73-94.

Polunin, N.V.C. (1984) Do traditional 'marine reserves' conserve? A view of Indonesian and New Guinean evidence. Senri Ethnological Studies, 17, 267-283.

Pratchett, M.S., Munday, P.L., Wilson, S.K., Graham, N.A.J., Cinner, J.E., Bellwood, D.R. et al. (2008) Effects of climateinduced coral bleaching on coral-reef fishes-ecological and economic consequences. Oceanography and Marine Biology: An Annual Review, 46, 251-296.

Russ, G.R., Stockwell, B. \& Alcala, A.A. (2005) Inferring versus measuring rates of recovery in no-take zones. Marine Ecology Progress Series, 292, 1-12.

Seber, G.A.F. (1984) Multivariate Observations. Wiley, New York, USA.

Thornburn, C.C. (2000) Changing customary marine resource management practice and institutions: The case of Sasi Lola in the Kei Islands, Indonesia. World Development, 28, 1461-1479.

Thornburn, C.C. (2001) The house that poison built: customary property rights and the live food fish trade in the Kei Islands, Southeast Maluku. Development and Change, 32, 151-180.

TiraA, A. (2006) Ra'ui in the Cook Islands-today's context in Rarotonga. SPC Traditional Marine Resource Management and Knowledge Information Bulletin. Noumea, New Caledonia, 19, 11-15.

Tyler, E.H.M., Manica, A., Jiddawi, N. \& Speight, M.R. (2011) A role for partially protected areas on coral reefs: maintaining fish diversity? Aquatic Conservation: Marine and Freshwater Ecosystems, 21, 231-238.

Varkey, D.A., Ainsworth, C.H., Pitcher, T.J., Goram, Y. \& Sumaila, R. (2010) Illegal, unreported and unregulated fisheries catch in Raja Ampat Regency, Eastern Indonesia. Marine Policy, 34, 228-236.

\section{Biographical sketches}

STUART CAMPBell's research interests include conservation biology. Joshua Cinner's research explores how social, economic, and cultural factors influence the ways in which people use, perceive and govern natural resources, with a particular emphasis on using applied social science to inform coral reef management. RizY A A RDIWIJAYA designs and applies monitoring programmes to provide the ecological information necessary for the effective management of marine protected areas. SHINTA PARDEDE's research interests include coral reef fish ecology. TASRIF KARTAWIJAYA's research interests include the management of coral reef fisheries. A HM AD MUKM UNIN works to encourage dialogue between government and communities to promote coral reef conservation. He has been managing the Wildlife Conservation Society research programme in Aceh for 5 years. YUDI HERdiana's research interests include the ornamental fish trade. ANDREW HOEY's research interests include the functional importance of herbivorous fishes on coral reefs. MORGAN PRATCHETT's research interests include the role of disturbance on coral reefs and the effect of climate change on fisheries. ANDREW BAIRD's research interests include the evolution of life histories in corals. He has been engaging with the reefs of Aceh since 1984. 